Logos Universality Mentality Education Novelty, Section: LAW

ISSN: 2284 - 5968 (print), ISSN: 2284 - 5968 (electronic)

Covered in: CEEOL, Index Copernicus, Ideas RePeC, EconPapers, Socionet

\title{
TRADITION AND INNOVATION IN LEGAL SCIENCES
}

\author{
Denisa $B A R B U$
}

Doi: http://dx.doi.org/10.18662/lumenlaw.2015.0401.01

Logos Universality Mentality Education Novelty, Section: LAW, 2015, Volume IV, Issue 1, pp: 5-8

Published by:

Lumen Publishing House

On behalf of:

Lumen Research Center in Social and Humanistic Sciences 


\title{
Tradition and Innovation in Legal Sciences
}

\section{Denisa BARBU 1}

\begin{abstract}
Starting from the ideas of some illustrious jurists as Piccard, Francois Gabby, we can say that over the ages there have been changes, the legal institutions have evolved, but at the same time, there were elements of continuity from one historical era to another, of institutions, ideas, concepts, on the legal phenomenon. Regarding this, a series of studies are raising a number of questions: whether we could identify, besides some immediate changes of legislation compatible with the new established order, and some elements of continuity with the past order.
\end{abstract}

Keywords: tradition, innovation, legal sciences, laws, rules.

1 Assistant Professor PhD, Valahia University of Targoviste, Faculty of Law and Administrative Sciences, The Department of Administrative Sciences, Romania, denisa.barbu77@yahoo.com.

Barbu, D. (2015). Tradition and Innovation in Legal Sciences. Logos Universality Mentality Education Novelty, Section: LAW, IV (1), 5-8. Doi: http://dx.doi.org/10.18662/lumenlaw.2015.0401.01 
These aspects have been analysed and argued, in a deep way by the Academician Ion Gheorghe Maurer (Maurer, Ion Gheorghe, 1956), who concluded:

"Romanian law evolution is not only an immediate and total passing from a company based on the exploitation of a new society, but also reveals elements of continuity as a result of the existence of regulatory needs identical from one historic stage to another."

We believe that the law is not exhausted through the formulation of normative provisions, but also takes into account some realities that preexist, to the previous norm, responding however to some necessities. The legislature did not invent rules, but merely formulates them, giving the corresponding expression targets that require some regulation or another. Scientists studying the objective laws act in the sphere of legal regulation cannot ignore the fact that, alongside the institutions, concepts, the right includes both shifting from one type of company to another, and the constant elements, reflecting the needs of common regulation to several types of society.

Therefore, we emphasize both the rules and the variable side of new legal concepts, but also elements of continuity with the theories and ideas with scientific content from the past law organization.

Along time, we observe an identified trend primarily through the legislative, a concern for mobility, identifying new solutions, amending existing provisions to supplement the content rules, all of which have as the objective of transformation of the law into an instrument of political-legal, setting up a new company alleged to be better adapted to the demands of new political and legal approaches.

The entry into force of the new legislative codes (civil - 01.10.2011, civil procedure -15.02.2013, criminal and criminal procedure - 29.01.2014), brought a series of changes in the legal environment.

The civil codes have had as a prerequisite, on the one hand, inter alia, the elimination of the deficiencies of the judicial system, focusing on the achievement of the civil unitary practice at the level of the courts, speeding up the settlement of cases, a clear and detailed definition of the principles of the civil trial. On the other hand, the modernization of regulating the civil legal relations inter alia by affirming the private law unit, changing the design with respect to the heritage and to the extinctive prescription, regulating uniform and detailed rights of persons and their defense and of obligations of matters in concurring with the European tendencies. 
Also, criminal codes have changed from criminal liability: the separation of the judiciary, the functions in the criminal procedure, introducing the institution of the judge of rights and freedoms and that of the judge of the preliminary room; the amendment by introducing the preventive measures to home-arrest, introducing the days-fine, offences affecting privacy of the domicile and the private life and the list could continue.

From this perspective, we propose an analysis of the new regulatory framework, which was designed to be a modern and fully responding to the imperatives of operation for a modern justice, adapted to social expectations and need for increasing the quality of this public service.

The influx of the normative acts have been imposed by the need to find fast and efficient answers of such economic and social processes that, in reality, would have needed a long time to become settled and to produce convincing results. The mobility of legal rules has been determined and new realities, such as the intensification of some, such us, organized crime, terrorism, trafficking and consumption of drugs, trafficking in human beings, economic offences, offences committed by the civil clerks.

The need for in-depth knowledge of legal rules should be re-thought, nuancing the legal system with the primordial rule of law order keeping, generated primarily by the particularities of the law and of international relations, taking into account the fast pace and the myriad changes in the links among States for the need of knowing the limits within which the international sanctions may affect the sovereignty of the State.

In the field of law, tradition and innovation in legal sciences bring together scientists concerned with classical issues of law; for legislative reforms arising internally, at the European and international levels and in trends of modern laws unification of legal rules in different branches of the legal sciences ${ }^{2}$.

In conclusion, the touch of originality and the unity of the studies will result from the conjunction of two elements: on the one hand, attention should be given to classical aspects involving the study of legal and social sciences, and on the other hand, it will make way, with relevant arguments, modern, European perspective, on the international basis.

Such a scientific approach contributes to the elaboration of a genuine general theory of legal rules, with the effect of the reflection for the

${ }^{2}$ LUMEN International Conference Tradiție si reforma, second edition, November 2013. 
theoretical solutions released into reconsidering of the legal system, in order to achieve its functions more effectively.

We shall hope that the changes made in the legislative field will contribute to strengthening the decisive legal order and the improvement of the functioning of the institutions that ensure the order and the discipline in social relationships.

\section{References}

Maurer, I. G. (1956). Cuvânt-înainte. Studii și Cercetări Juridice, 11, pp. 5-6.

\section{Biodata}

\section{Assistant Professor PhD Denisa BARBU}

Bachelor of the Faculty of Law, Bucharest, Specialisation Law (2001); Master in „European Public Administration”, University „Valahia ” of Targoviste, Faculty of Juridical, Social and Political Sciences ,(20042005); PhD in Law, Magna cum Laude, from the Institute of Juridical Research „Acad. Andrei Radulescu”, Romanian Academy (2014).

Activity: Assistant Professor in University „Valahia ” of Targoviste, Faculty of Law and Administrative Sciences; lawyer, Dambovita Bar (2002 present); member of the Romanian Asociation of Criminal Sciences (2011present); member of Romanian Society of European Law (2014); over 35 published articles in the domain of International Criminal Law, International Litigations, Criminal Procesual Law, for example: „The Main Role of the International Tribunal in Accordance with Preventing and Repressing International Crimes”, „Responsibility of States for not Enforcing the International Jurisdiction Act”, „Tehniques of enforcements of International Jurisdiction Acts”, „The Agreement on the Recognition of Guilt” etc.

Barbu, D. (2015). Tradition and Innovation in Legal Sciences. Logos Universality Mentality Education Novelty, Section: LAW, IV (1), 5-8. Doi: http://dx.doi.org/10.18662/lumenlaw.2015.0401.01 